\title{
ANALISIS ETIKA KERJA ISLAM PADA KINERJA KARYAWAN BPRS MAU BANDAR LAMPUNG
}

\author{
Ansyori Ahmad \\ Pascasarjana Universitas Islam Negeri (UIN) Raden Intan Lampung \\ ansyoriahmad25@gmail.com
}

\begin{abstract}
In this era, the world has developed. Thus, it requires a company to be able to compete and survive in the business. As a consequence, a company must be more effective and efficient in conducting its operational activities in order to ensure the survival of the company. The success of the company's operational activities can't only be seen from the quality products it produces, but also from the services provided and the work ethic of the Human Resources in the company. And then, this research aimed to analyze how the application of Islamic work ethics to employees of BPRS Mitra Agro Usaha Bandar Lampung and how the application of Islamic work ethics affects the performance of employees of BPRS Mitra Agro Usaha Bandar Lampung. This research used field research with a qualitative approach and descriptive. Data collection used interviews and observations. The results of the research showed that employees of BPRS Mitra Agro Usaha Bandar Lampung had reflected the true work ethic of Muslims by applying the characteristics of Islamic work ethics such as honesty, discipline, creativity, being responsible, happy. Because they served and being independent in order to make BPRS Mitra Agro Usaha a transitioning Financing Bank from conventional to Sharia Financing Bank. The Bank completely applies Sharia working principles as per Islamic teachings. Furthermore, the application of Islamic work ethics had a positive impact on the performance of employees of PT. BPRS Mitra Agro Usaha Bandar Lampung.
\end{abstract}

Keywords: Islamic Work Ethic, Employee Performance.

\section{Pendahuluan}

Etika dibentuk oleh budaya, kebiasaan, serta sistem nilai yang diyakininya. Bersumber dari bahasa Yunani, ethikos memiliki makna yang beragam: yaitu, sebagai analisis berbagai konsep tentang benar salah, tugas, apa yang harus, tanggung jawab, wajib, mesti, aturanaturan moral, dan lain sebagainya, kemudian, pencarian ke dalam watak moralitas tindakantindakan moral, dan terakhir adalah pencarian terhadap suatu kehidupan yang secara moral adalah baik (Farisul Adab, 2015). Adapun etika merupakan seperangkat nilai tentang baik atau buruk, benar atau salah yang didasarkan pada prinsip moralitas, terutama pada perilaku dan tindakan. Oleh karena itu, etika menjadi faktor utama dalam mewujudkan kondisi kehidupan manusia yang lebih baik (Arifin, 2007). Etika kerja Islam berperan untuk menciptakan perilaku kerja yang positif pada suatu individu. Prinsip kerja keras, komitmen dan moral yang menjadi penekanan pada konsep ini akan memberikan hasil yang positif, baik bagi individu maupun organisasi (Diana Ma'rifah, 2013).

Pada dasarnya etika kerja Islam yang bersumber dari syariah mendedikasikan kerja sebagai kebajikan (Fitria, 2013). Islam menuntun kita untuk selalu bekerja dengan rajin, tetapi hasil kerja bukan hanya untuk diri sendiri, namun dapat bermanfaat juga bagi orang lain (Heppy Harmoko, t.t). Etika sering diidentikan dengan dengan moralitas, akhlak, dan adab (dalam bahasa arab). Beberapa faktor yang dapat mempengaruhi apakah seseorang bersikap etis atau tidak etis dalam aktivitas bisnis yang dilakukan, tentu saja faktor itu tidak tunggal, tetapi jamak diantaranya adalah karena faktor internal dalam diri manusia sebagai subjek pelaku, selain juga karena faktor lingkungan (eksternal) yang berada disekitar mereka (Andayani, 2016). Jika etika kerja islami yang tinggi dimiliki seseorang maka mereka akan memiliki akhlak yang baik untuk berpartisipasi dan terlibat dalam pekerjaan dengan cara yang baik (Ikhsan Maksum, 2020). Adapun aspek etika kerja muslim yang akan dijadikan indikator etika kerja muslim pada penelitian ini ada berdasarkan teori menurut Toto Tasmara

DOI: 10.33603/ejpe.v9i1.4507 
yaitu kejujuran, disiplin, kreatif, bersikap tanggung jawab, bahagia karena melayani dan bersikap mandiri (Tasmara, 2002). Dan untuk mengukur kinerja karyawan, digunakan teori menurut Fuad Mas'ud yaitu kualitas, kuantitas, ketepatan waktu, efektivitas, dan komitmen kerja (Mas'ud, 2004).

Etika kerja Islam memiliki peran yang patut untuk mendapatkan perhatian secara khusus karena memiliki pengaruh terhadap kinerja karyawan yang memiliki pengaruh pada keberhasilan suatu perusahaan atau dalam mencapai apa yang menjadi tujuannya, karena visi misi dan strategi perusahaan akan berjalan jika memiliki kinerja karyawan yang baik (Diana Sari Harahap, 2019). Kinerja karyawan ini nantinya akan dinilai dalam bentuk pengukuran kinerja, sejauh mana karyawan tersebut dapat menerapkan etika kerja yang telah dibuat oleh perusahaan. Hal ini telah buktikan oleh hasil penelitian yang dilakukan oleh Haerudin bahwa etika kerja Islam mempunyai pengaruh terhadap variabel komitmen organisasi, sikap pada perubahan, kepuasan kerja, kepuasan hidup, kinerja pegawai, kemampuan berinovasi dan keterlibatan kerja (Haerudin, 2015).

Menurut Mangkunegara kinerja berasal dari kata Job Performance atau Actual Performance (prestasi kerja atau prestasi yang sesungguhnya dicapai oleh seseorang), serta pengertian kinerja (prestasi kerja) adalah hasil kerja secara kualitas dan kuantitas yang dicapai oleh seorang karyawan dalam melaksanakan tugasnya sesuai dengan tanggung jawab yang diberikan kepadanya (Mangkunegara, 2000). Menurut Robbins kinerja merupakan hasil evaluasi tehadap pekerjaan yang telah dilakukan dengan kriteria yang telah ditetapkan bersama (Robbins, 1986). Adapun kinerja seorang karyawan merupakan prestasi kerja yang dapat mencerminkan perbandingan antara hasil kerja yang diperoleh dengan standar yang telah ditentukan sebelumnya. Untuk mencapai kinerja karyawan yang optimal maka perlu dilakukan pengelolaan sumber daya manusia yang berkaitan dengan kompensasi, lingkungan kerja dan kepemimpinan (Hamdiyah, 2016). Pada pengertian lain, kinerja pegawai adalah hasil kerja pegawai secara keseluruhan atau selama periode tertentu baik secara kualitas maupun kuantitas berdasarkan kriteria yang telah ditentukan dan disepakati terlebih dahulu (Ririn Nur Indah Sari, 2016). Kinerja pegawai sangatlah penting karena memiliki pengaruh terhadap kinerja perusahaan (Fachreza, 2018).

Di dalam lembaga keuangan yang berbasis Syari'ah, acuan yang digunakan dalam menerapkan etika kerja adalah berdasarkan Al-Qur'an dan Hadits. BPRS (Bank Pembiayaan Rakyat Syari'ah) merupakan salah satu jenis perbankan Syari'ah yang ada di Indonesia. BPRS adalah suatu lembaga keuangan yang dalam bertransaksi memenuhi kebutuhan masyarakat yang berdasarkan prinsip syari'ah (Sholahuddin, 2006). Saat ini, strategi pengembangan perbankan syariah secara nasional meruju pada cetak biru (blue print) bank syariah yang diformulasikan oleh Bank Indonesia (Iwan Setiawan, 2019). Dan difokuskan pada Usaha Mikro, dan Kecil (UMK) yang kemudian membuat BPRS mempunyai pangsa pasar yang berbeda dengan Bank Syariah dan lembaga keuangan lainnya (Fauzi, 2018).

Di antara lembaga BPRS yang ada di Indonesia adalah BPRS Mitra Agro Usaha yang berdomisili di Kota Bandar Lampung. Pada masa awal berdirinya disebut sebagai Bank BPR (Bank Perkereditan Rakyat). Kemudian setelah terbut Surat Keputusan Gubernur Bank Indonesia Nomor 15/81/KEP.GBI/DPG/2013 pada tanggal 23 Juli 2013 tentang pemberian izin perubahan kegiatan Usaha Bank Perkereditan Rakyat (BPR) menjadi Bank Pembiayaan Rakyat Syari'ah (BPRS), PT. BPRS Mitra Agro Usaha bertransformasi dari BPR yang merupakan bank konvensional dan BPRS Mitra Agro Usaha Bandar Lampung adalah satusatunya lembaga BPRS 'muallaf' dan menjadi objek pada penelitian ini. 
Meskipun penelitian-penelitian sebelumnya mengambil tema yang sama dengan penelitian ini yaitu tentang hubungan etika kerja Islam terhadap kinerja karyawan, penelitianpenelitian sebelumnya sebagai rujukan peneliti untuk meneliti dengan tema yaitu analisis etika kerja islam pada kinerja karyawan di PT. BPRS Mitra Agro Usaha Bandar Lampung. Penelitian dilakukan dengan melihat etika kerja Islam sehingga dapat meningkatkan kinerja karyawan. Dan peneliti sadar bahwa penelitian ini telah berkali-kali dilakukan, namun peneliti melihat sisi lain, yaitu pada situasi, konteks dan fokus penelitian atau bahasan yang berbeda.

Penelitian ini dilakukan bertujuan untuk mengetahui bagaimana penerapan etika kerja Islam pada BPRS Mitra Agro Usaha Bandar Lampung dan bagaimana penerapan etika kerja Islam berdampak pada kinerja karyawan pada BPRS Mitra Agro Usaha Bandar Lampung.

\section{Metode Penelitian}

Penelitian ini adalah suatu penelitian lapangan atau field research dengan menggunakan pendekatan kualitatif dan bersifat deskriptif. Berdasarkan rancangan tersebut, maka peneliti menggali informasi pada obyek penelitian berdasarkan persepsi penulis dan orang yang diwawancarai, sehingga informasi yang didapat pada proses wawancara dapat berkembang sesuai dengan interaksi yang terjadi. Kemudian peneliti menginterpretasikan makna yang tersirat dan tersurat dari keterangan yang diperoleh dari pihak yang diwawancarai, hasil observasi lapangan serta catatan pribadi.

Data primer bersumber dari hasil wawancara dan observasi berkaitan dengan masalah yang dihadapi. Data primer ini diperoleh dari pihak-pihak yang terlibat secara langsung dengan fokus yang diteliti yaitu manajer dan karyawan. Selanjutnya data yang diperoleh dari lapangan diolah dengan teknik analisis deskriptif kualitatif. Analisis data dilakukan dengan tiga tahapan, yakni reduksi data, penyajian data dan verifikasi atau penarikan kesimpulan.

Sebagai gambaran masalah yang akan dibahas, maka dibuatlah kerangka pemikiran sebagai berikut, sebagai landasan dalam meneliti masalah serta untuk menemukan, mengembangkan dan menguji kebenaran terhadap suatu penelitian:

\begin{tabular}{|c|c|}
\hline $\begin{array}{l}\quad \text { Etika Kerja Islam } \\
\text { 1. Kejujuran } \\
\text { 2. Disiplin } \\
\text { 3. Kreatif } \\
\text { 4. Bersikap tanggung jawab } \\
\text { 5. Bahagia karena melayani }\end{array}$ & $\begin{array}{l}\text { Kinerja Karyawan } \\
\text { 1. Kualitas } \\
\text { 2. Kuantitas } \\
\text { 3. Ketepatan Waktu } \\
\text { 4. Efektivitas } \\
\text { 5. Komitmen kerja }\end{array}$ \\
\hline Analisis Etika Kerja Islam & $\begin{array}{l}\text { wan PT BPRS Mitra Agro } \\
\text { ng }\end{array}$ \\
\hline
\end{tabular}

\section{Hasil dan Pembahasan}

Berdasarkan pada hasil penelitian yang telah peneliti lakukan, hasil lapangan menunjukan bahwasannya berdasarkan pada teori yang ada dalam Toto Tasmara di atas, implementasi etika kerja Islam yang terdapat di BPRS Mitra Agro Usaha atau yang disingkat BPRS MAU terdapat kesesuaian diatara teori dan praktek. Berikut ini adalah penjelasannya: 


\section{Kejujuran}

Berdasarkan hasil penelitian yang diperoleh dari lapangan bahwasannya kejujuran yang ada pada BPRS MAU dibuktikan dengan etika kerja karyawan seperti:

1. Tidak menerima imbalan dalam bentuk apapun dari nasabah pembiayaan BPRS MAU agar dapat mempermudah proses pengajuan pembiayaan.

2. Tidak menerima imbalan apapun dari nasabah BPRS MAU bila telah mendapatkan pencairan dana pembiayaan.

3. Tidak melindungi nasabah yang termasuk dalam kategori nasabah pembiayaan bermasalah pada BPRS MAU

Dengan adanya sifat jujur para karyawan, maka operasional BPRS MAU dapat berjalan dengan baik dan diharapkan tidak akan merugikan pihak manapun serta akan menimbulkan keadilan bagi semua pihak. Begitu juga dalam transaksi dengan para nasabah, jika kedua belah pihak berlaku jujur dan terus terang, maka keduanya akan mendapat keberkahan.

\section{Disiplin}

Kedisiplinan sangat dibutuhkan bagi badan usaha seperti BPRS MAU Bandar Lampung. Berdasarkan penelitian kedisiplinan pada BPRS MAU diwujudkan:

1. Ketepatan waktu masuk kantor dan keluar kantor

2. Absensi kepegawaian

3. Kedisiplinan dalam mencapai target tahunan.

Dalam suatu perusahaan disiplin kerja adalh faktor yang paling penting untuk mencapai kelancaran operasional perusahaan tersebut. Disiplin kerja adalah sarana komunikasi yang digunakan oleh atasan dengan bawahannya, juga oleh sesama pegawai dalam suatu perusahaan untuk mewujudkan tujuan bersama.

Penekanan terhadap kedisiplinan yang dilakukan kepada karyawan BPRS MAU bukanlah sebuah pemberian beban terhadap bawahan melainkan melatih karyawan untuk memiliki etika kerja yang baik untuk mencapai tujuan bersama BPRS MAU Kota Bandar Lampung.

\section{Kreatif}

Tingginya persaingan bisnis saat ini, mau tidak mau perusahaan harus memiliki inovasi yang tinggi yang pastinya inovasi tersebut akan lahir dari para karyawan yang kreatif. Bagi lembaga keuangan seperti BPRS MAU sebagai lembaga bisnis sekaligus jasa pelayanan masyarakat sangatlah membutuhkan kreatifitas untuk mengembangkan dan mengepakkan sayapnya didunia perekonomian saat ini.

Semakin kesini dunia perbankan telah menunjukkan eksistensinya oleh sebab itu untuk mempertahankan dirinya BPRS MAU melakukan penampungan aspirasi, invasi serta kreatifitas yang baik dan positif yang diberikan oleh anggotanya untuk membangun BPRS MAU serta mampu menyaingi berbagai lembaga keuangan lainnya secara sehat dan sesuai dengan syariat Islam.

Untuk meingkatkan kreatifitas kerjanya BPRS MAU selalu mengadakan pertemuan seluruh pengurus setiap akhir bulan, dalam pertemuan tersebut Direksi selalu menghimbau agar para karyawan untuk memberikan ide-ide dan saran yang berguna untuk membenahi pengelaloan BPRS MAU dan Direksi sangat menyarankan agar adanya inovasi dari bawah (karyawan) ke atas (Direksi).

Bersikap Tanggung Jawab

p-ISSN 2337-571X | e-ISSN 2541-562X

(C) 2020 Edunomic: Jurnal Ilmiah Pendidikan Ekonomi Fakultas Keguruan dan Ilmu Pendidikan 
Bersikap tanggung jawab merupakan salah satu etika kerja Islam yang diterapkan oleh BPRS MAU Bandar Lampung. Sikap tanggung jawab yang ada BPRS MAU diwujudkan dalam bentuk sebagai berikut :

1. Setiap kariyawan BPRS MAU melakukan tugasnya berdasarkan job description masingmasing.

2. Jika terjadi pembiayaan bermasalah maka pihak $A O$ selaku bagian pembiayaan harus mampu mempertanggung jawabkannya seperti melakukan penagihan kepada nasabah untuk membayar pembiayaannya pada BPRS MAU tentunya penagihan yang dilakukan tidak melanggar aturan-aturan syariat Islam.

3. Jika terjadi permasalahan baik didalam maupun diluar kantor setiap karyawan yang bersangkutan wajib melaporkan kepada direksi dan mempertanggung jawabkan tugasnya masing-masing.

\section{Bahagia Karena Melayani}

Berdasarkan pada hasil penelitian bahwasannya kondisi yang ada pada BPRS MAU dalam menjaga kualitas pelayanannya terhadap masyarakat semua karyawan BPRS MAU, diharapkan selalu professional dalam mejalankan tugasnya terutama bila bertemu nasabah. Setiap karyawan dituntut untuk senang, gembira serta bahagia bila bertemu nasabah. Hal tersebut dapat dilihat dari proses pelayanan karyawan BPRS MAU dengan berlaku sopan santun kepada nasabah, menyambut kedatangan nasabah dengan baik serta melayani nasabah dengan penuh kesabaran.

\section{Bersikap Mandiri}

Berdasarkan hasil penelitian sikap mandiri yang ada pada BPRS MAU diwujudkan:

1. Kegiatan yang dilakukan oleh karyawan itu sendiri menjalankan tugasnya berdasarkan job description yang telah diberikan.

2. Dalam mewujudkan sikap mandiri pada karyawan BPRS MAU melakukan training bagi pegawai barunya agar mampu melakukan tugas dan tanggung jawabnya secara individu.

Kemudian berdasrakan hasil analisa penerapan etika kerja Islam berpengaruh terhadap kinerja karyawan Pada BPRS MAU Bandar Lampung, dapat diketahui kinerja karyawan sebagai berikut :

\section{Kualitas}

Kualitas kerja diukur dari persepsi terhadap kualitas pekerjaan yang dihasilkan serta kesempurnaan tugas terhadap keterampilan dan kemampuan karyawan. Selain itu diukur juga dengan hasil aktivitas yang dilakukan mendekati sempurna dalam arti menyesuaikan beberapa cara ideal dari penampilan aktivitas ataupun memenuhi tujuan yang diharapkan dari suatu aktivitas. Berdasarkan hasil penelitian yang telah peneliti lakukan kualitas kerja yang terdapat di BPRS MAU Bandar Lampung dapat dilihat:

1. Pelayanan yang diberikan oleh BPRS MAU kepada nasabah, sejauh ini belum pernah ada komplain dari nasabah mengenai pelayanan yang diberikan oleh karyawan. Ini merupakan dampak dari pelayanan kepada nasabah merupakan pelayanan yang didasari oleh rasa bahagia ketika dapat memberikan pelayanan terbaik kepada nasabah. Memberi pelayanan dan pertolongan merupakan investasi yang kelak akan dipetik keuntungannya, tidak hanya di akhirat, tetapi di duniapun mereka sudah merasakannya. Ketika seorang karyawan bekerja dilandasi dengan rasa bahagia dalam melayani, maka akan menghasilkan hasil kerja yang berkualitas, sebagaimana yang telah dilakukan oleh karyawan BPRS MAU Bandar Lampung.

2. Tugas dan tanggung jawab yang dijalankan oleh karyawan seperti yang telah dijelaskan pada analisis sebelumnya merupakan wujud dari kualitas kinerja yang ada pada karyawan 
BPRS MAU Bandar Lampung. Tanggung jawab yang diterapkan oleh karyawan BPRS Mitra Agro Usaha sampai saat ini sangat baik, bisa dilihat dari cara mengatasi berbagai masalah, baik yang terdapat di lapangan maupun di kantor. Bagi BPRS MAU tanggung jawab adalah bentuk eksistensi yang menunjukkan kualitas dalam etika kerja. Bagi BPRS MAU Bandar Lampung, kerja itu tidak sekedar mencari uang, tetapi merupakan bentuk aktualisasi hakekat kerja itu secara totalitas dan bernilai transendetal yang luhur. Sebagaimana yang diungkapkan oleh Gita bahwa tanggung jawab karyawan dapat dibuktikan berdasarkan hasil kerja di lapangan dan di kantor atau berdasarkan penyelesaian permasalahan di kantor atau di lapangan. Contoh permasalahan yang terjadi di lapangan yaitu ketika seorang Accountig Officer mengalami nasabah macet maka Accounting tersebut harus bertanggung jawab dengan melakukan penagihan kepada nasabah dengan cara baik sesuai syar'ah Islam. Dan kita harus melaporkan permasalahan tersebut kepada direksi yang bertanggung jawab pada organisasi atau lembaga dan direksi harus turut ikut menyelesaikan masalah tersebut. Ketika sulit diselesaikan maka direksi memberikan laporan kepada pengurus agar permasalahan tersebut segera ditindak lanjut, itulah bentuk tanggung jawab yang diterapkan oleh BPRS MAU.

3. Yang tidak kalah pentingnya adalah kejujuran. Kejujuran harus dimiliki oleh para karyawan. Kejujuran dan kepercayaan menjadi tolok ukur bagi nasabah, supaya tetap memberi kepercayaan kepada BPRS MAU. Tingkat kejujuran yang ditanamkan setiap karyawan dalam memberikan suatu pelayanan bagi nasabah terus dipantau oleh direksi. Ketika terjadi penyuapan kepada karyawan dari nasabah yang ingin melakukan pengajuan pembiayaan, maka karyawan tidak akan menerima pemberian dari si nasabah apabila dana tersebut dicairkan. Ketika kedapatan karyawan yang melakukan hal yang melanggar nilai kejujuran, maka akan mendapatkan sangsi dari direksi. Sejak dahulu, direksi selalu menghimbau kepada semua karyawan agar tidak melakukan hal tersebut. Salah satu contoh jaminan kejujuran tersebut, tidak pernah ada nasabah yang merasa kehilangan atau dirugikan secara materil. Ketika seorang karyawan bekerja dengan jujur, maka akan menghasilkan kerja yang berkulitas atau minimal dia tidak akan melakukan suatu pelanggaran kerja yang dapat merugikan berbagai pihak.

\section{Kuantitas}

Kuantitas adalah jumlah yang harus diselesaikan atau dicapai. Pengukuran kuantitatif melibatkan perhitungan keluaran dari proses atau pelaksanaan kegiatan. Ini berkaitan dengan jumlah keluaran yang dihasilkan. Kuantitas yang terdapat pada BPRS MAU Bandar Lampung adalah sebagai berikut:

1. Seberapa besar karyawan BPRS MAU Bandar Lampung mampu mencapai target baik dalam bentuk bulana maupun tahunan.

2. Peningkatan-peningkatan baik jumlah nasabah pembiayaan maupun penyimpanan yang terdapat pada BPRS MAU Bandar Lampung merupakan wujud kuantitas kinerja karyawan BPRS MAU Bandar Lampung.

3. Kemudian mengukur kuantitas kerja dari jumlah tugas yang dapat diselesaikan oleh para karyawan BPRS MAU Bandar Lampung dalam kurun waktu yang ditentukan.

Semuanya merupakan implikasi dari penerapan kedisiplinan para karyawan BPRS MAU Bandar Lampung. BPRS MAU Bandar Lampung mengutamakan kepentingan bersama di atas kepentingan pribadi. Semua pengelolaan dibangun dengan rasa kekeluargaan, sehingga akan tumbuh rasa saling melindungi dan menanggung. Dalam hal penerapan kedisiplinan BPRS MAU mempunyai kedisiplinan yang tinggi. Bisa dilihat dari karyawan BPRS MAU yang selalu berusaha datang kerja tepat waktu, akan ada beberapa karyawan 
yang masih belum bisa melaksanakan disiplin tersebut dikarena alasan yang masih bisa ditolerir.

\section{Ketepatan Waktu}

Ketepatan waktu merupakan tolak ukur kinerja sebuah perusahaan, lembaga, instansi maupun organisasi. Dengan ketepatan waktu yang ada selain mampu mengefektifkan waktu hal tersebut juga dapat mengefesiensikan biaya.

Ketepatan waktu yang ada pada BPRS MAU Bandar Lampung dapat dibuktikan dengan ketepatan karyawan BPRS MAU Bandar Lampung dalam menyelesaikan tugasnya seperti :

1. Melakukan penagihan nasabah pembiayaan sebelum ganti bulan ataupun ganti tahun yang dalam hal ini dilakukan oleh bagian account officer.

2. Menyelesaikan laporan keuangan sebelum waktu yang ditentukan habis. Dalam hal ini tugas dan tanggung jawab dilakukan oleh bagian teller dan accounting yang ada pada BPRS MAU Bandar Lampung.

\section{Efektivitas}

Konsep efektivitas dapat diartikan sebagai pemanfaatan sarana, prasaran dan sumber daya dalam jumlah tertentu yang secara sadar ditentukan sebelumnya untuk menghasilkan sejumlah barang atas jasa kegiatan yang dijalankannya.Efektivitas menunjukkan keberhasilan dari segi tercapai tidaknya sasaran yang telah ditetapkan. Ketika hasil aktivitas semakin mendekati sasaran, berarti makin tinggi efektivitasnya. Efekivitas yang ada pada BPRS MAU Bandar Lampung dapat dikategorikan cukup baik dengan pencapaian-pencapaian yang terdapat di BPRS MAU Bandar Lampung seperti memenuhi target, member kualitas pelayanan yang baik bagi nasabah serta mampu mengendalikan masalah-masalah baik itu pembiayaan dan pendanaan secara baik.

\section{Komitmen Kerja}

Konsep komitmen merupakan sesuatu yang membuat seseorang membulatkan hati, berkorban, bertanggungjawab dan bertekad berjerih payah demi mencapai tujuan dirinya dan tujuan organisasi atau perusahaan yang telah disepakati atau ditentukan sebelumnya. Komitmen memiliki peranan penting terutama pada kinerja seseorang ketika bekerja,hal ini disebabkan oleh adanya komitmen yang menjadi acuan serta dorongan yang membuat mereka lebih bertanggung jawab terhadap kewajibannya. Komitmen yang ada pada BPRS MAU adalah seperti pemberian sanksi bagi karyawan yang melanggar aturan perusahaan sesuai dengan tata tertib serta aturan-aturan yang ada di BPRS MAU Bandar Lampung.

Berdasarkan hasil penelitian mengenai Etika Kerja Islam Terhadap Kinerja Karyawan pada BPRS MAU Bandar Lampung yang telah peneliti paparkan diatas. Bahwasannya BPRS MAU yang merupakan konversi bank konvensional menunjukkan peralihan dari konvesioal meuju syariah bukanlah hanya merubah labelnya saja melainkan selruh aspek-aspeknya pun dirubah, termasuk etika kerja yang ada pada karyawan BPRS MAU Bandar Lampung.

Islam sebagai agama yang sempurna telah mengatur segala kegiata manusia jauh sebelum manusia lahhir dimuka bumi. Sebagai muslim yang baik, semestinya kita senantiasa mengikuti perintahnya dan menjauhi larangannya, sama hal nya yang dilakukan oleh BPRS MAU Bandar Lampung menjadi BPRS MAU Bandar Lampung. Dengan demikian apapun yang kita lakukan bukan hanya semata-mata untuk meraih maslahah didunia saja namun untuk meraih fallah didunia dan akhirat. 


\section{Simpulan}

Kesimpulan dari hasil penelitian adalah karyawan pada BPRS MAU Bandar Lampung telah mencerminkan etika kerja muslim yang sesungguhnya dengan menerapkan ciri-ciri etika kerja islam seperti kejujuran, disiplin, kreatif, bersikap tanggung jawab, bahagia karena melayani serta bersikap mandiri guna menjadikan BPRS MAU yang merupakan Bank Pembiayaan yang bertransisi dari konvensional menuju Bank Pembiayaan Syariah menjadi Bank yang seutuhnya menerapkan prinsip kerja Syariah sebagaimana dengan ajaran Islam. Kemudian penerapan etika kerja islam berdampak positif pada kinerja karyawan BPRS MAU Bandar Lampung.

\section{Referensi}

Andayani, D. (2016). Relasi Etika Kerja Dan Etos Kerja Dalam Islam. Inovatif 2 (2) , 149.

Arifin, J. (2007). Fikih Perlindungan Kosumen. Semarang: Rasail.

Diana Ma'rifah, A. I. (2013). Pengembangan Etika Kerja Berbasis Islam: Kajian Tentang Kepuasan Kerja, Komitmen Organisasional, dan Perilaku Kewargaan Organisasional. Journal \& Proceeding FEB UNSOED , 7.

Diana Sari Harahap, S. B. (2019). Pengaruh Etika Kerja Islam Terhadap Kinerja Pegawai dengan Kefektifan Komitmen sebagai Variabel Moderating. Jurnal ESTUPRO, 4 (1), 108.

Fachreza, S. M. (2018). Pengaruh Motivasi Kerja, Lingkungan Kerja dan Budaya Organisasi terhadap Kinerja Karyawan dan dampaknya pada Kinerja Bank Aceh Syariah di Kota Banda Aceh. Jurnal Magister Manajemen Fakultas Ekonomi dan Bisnis Unsyiah, 2 (1), 120 .

Farisul Adab, W. R. (2015). Pengaruh Etika Kerja Islam Terhadap Komitmen Organisasi, Retensi Karyawan dan Produktivitas. Equilibrium, 3 (1), 50.

Fauzi, M. (2018). Efisiensi Bank Pembiayaan Rakyat Syariah (BPRS) di Provinsi Jawa Tengah. Jurnal Ekonomi \& Keuangan Islam, 4 (1) , 32.

Fitria, A. (2013). Pengaruh Etika Kerja Islam Terhadap Sikap Akuntan Dalam Perubahan Organisasi dengan Komitmen Organisasi sebagai Variabel Intervening. EKUITAS, 3 , 443.

Haerudin. (2015). Etika Kerja Islam Sebuah Kajian Teoritik dan Empirik. Maksimum, 5 (1), 29.

Hamdiyah, A. T. (2016). Peningkatan Kinerja Karyawan Melalui Kompensasi, Lingkungan Kerja dan Gaya Kepemimpinan di ADA Swalayan Banyumanik Semarang. Journal of Management 2 (2), 5.

Heppy Harmoko, H. S. (t.t). Pengaruh Etika Kerja Islam dan Kepuasan Kerja Terhadap Kinerja Karyawan. e-Jurnal Riset Manajemen , 120.

Ikhsan Maksum, N. L. (2020). Kepemimpinan Islami dan Etika Kerja Islami: Pengaruhnya terhadap Kinerja Karyawan. Li Falah-Jurnal Studi Ekonomi Dan Bisnis Islam, 5 (1), 107.

Iwan Setiawan, D. J. (2019). Strategi Pengembangan Bank Pembiayaan Rakyat Syariah (BPRS) di Jawa Barat. Jurnal Ilmu Akuntansi dan Bisnis Syariah, l (2) , 167.

Mangkunegara, A. P. (2000). Manajemen Sumber Daya Manusia Perusahaan. Bandung: Rosda. 
Mas'ud, F. (2004). Survei Diagnosis Oragnisasional (Konsep dan Aplikasi). Semarang: Badan Penerbit Universitas Diponegoro.

Ririn Nur Indah Sari, H. S. (2016). Peningkatan Kinerja Pegawai Melalui Kepuasan Kerja dan Disiplin Kerja. Jurnal Pendidikan Manajemen Perkantoran, 1 (1) , 206.

Robbins, S. P. (1986). Organizational Behaviour: Concept, Controversies, and Application. Prentice-Hall, Englewood Cliffs New Jersey , 410.

Sholahuddin, M. (2006). Lembaga Ekonomi dan Keuangan Islam. Surakarta: MUP-UMS.

Tasmara, T. (2002). Membudayakan Etos Kerja Islami. Jakarta: Gema Insani Press. 